\title{
"The effect of monetary and financial variables on share prices of Jordanian commercial banks"
}

AUTHORS

ARTICLE INFO

RELEASED ON

RECEIVED ON

ACCEPTED ON

LICENSE
Hel Ajmi Jameel Al-Dhaimesh (D https://orcid.org/0000-0001-8377-8237

Hel Ajmi Jameel Al-Dhaimesh (2020). The effect of monetary and financial variables on share prices of Jordanian commercial banks. Banks and Bank Systems, 15(3), 147-159. doi:10.21511/bbs.15(3).2020.13

http://dx.doi.org/10.21511/bbs.15(3).2020.13

Friday, 25 September 2020

Monday, 03 August 2020

Tuesday, 08 September 2020

\section{(c) EY}

This work is licensed under a Creative Commons Attribution 4.0 International License

JOURNAL

"Banks and Bank Systems"

ISSN PRINT

$1816-7403$

ISSN ONLINE

$1991-7074$

PUBLISHER

LLC "Consulting Publishing Company "Business Perspectives"

FOUNDER

LLC "Consulting Publishing Company "Business Perspectives"
NUMBER OF REFERENCES

48
NUMBER OF FIGURES

0
NUMBER OF TABLES

1

(C) The author(s) 2022. This publication is an open access article. 


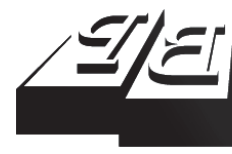

\section{BUSINESS PERSPECTIVES}

LLC "CPC "Business Perspectives" Hryhorii Skovoroda lane, 10, Sumy, 40022, Ukraine www.businessperspectives.org
Received on: $3^{\text {rd }}$ of August, 2020 Accepted on: $8^{\text {th }}$ of September, 2020 Published on: $25^{\text {th }}$ of September, 2020

(c) Hel Ajmi Jameel Al-Dhaimesh, 2020

Hel Ajmi Jameel Al-Dhaimesh, Ph.D., Professor, Department of Economics, Faculty of Economic and Administrative Sciences, The Hashemite University, Jordan.

\title{
THE EFFECT OF MONETARY AND FINANCIAL VARIABLES ON SHARE PRICES OF JORDANIAN COMMERCIAL BANKS
}

\begin{abstract}
This study aims to examine the effect of monetary and financial variables on share prices of Jordanian commercial banks for the period 2001-2018. The monetary variables used in the research include broad money supply, the interest rate on time deposits and inflation, while financial variables include both the deficit of the general budget and government expenditures, and the general government domestic debt. A multiple linear regression equation is designed using E-Views program to test this effect. The study shows that there is a significant positive effect of broad money supply, whereas a negative effect of the general budget deficit and a positive effect of the domestic debt on share prices of commercial banks in Jordan for the specified period. In contrast, there is no effect of both inflation and the interest rate on time deposits and government expenditures on the price of shares of Jordanian commercial banks. The study recommends taking into account the relationship between the variables mentioned in the prices of shares of commercial banks when setting monetary and financial policies by the central bank and the government to determine the extent to which these variables reflect share prices of Jordanian commercial banks. Overall, the regression model reached $\mathrm{R} 2=0.63$, and this means that $63 \%$ of the change in the share prices of Jordanian commercial banks is due to changes in the independent variables included in the model.
\end{abstract}

\section{Keywords}

JEL Classification

\section{INTRODUCTION}

A large volume of national and foreign savings is traded in the financial markets through the sale and purchase of shares and bonds. Many investors rely on these markets as the main source of entry, and any disruptions in the markets negatively affect the returns of investors. It is argued that monetary and financial variables are important in affecting share prices. Using these variables, the central bank and the government can follow a monetary and financial policy to stabilize stock markets. In particular, these markets are affected by expected and unexpected changes in the money supply. In general, developments in the national economy are based on the efficiency and performance of the stock market, which positively influences economic growth. The index numbers of share prices play an important role in predicting the performance of the stock market, since the changes in share prices indicate ups and downs of the trend in share prices as a sign of the performance of the market and the national economy together. Many studies conducted in both developed and emerging countries since the 1980s have shown a strong correlation between monetary and financial variables and share prices of companies traded in the financial markets. But these studies have reached results that seem different and conflicting in some cases. Therefore, this study aims 
to analyze the effect of monetary and financial variables on the index of share prices of Jordanian commercial banks, which many investors need to make the right decision to buy and sell shares at the Jordanian financial market.

\section{LITERATURE REVIEW}

The spread of literature linking monetary and financial variables to stock prices dates back to the late 1970s. These studies included developed and emerging financial markets and found a relationship between these variables and stock prices in the mentioned financial markets.

Omornyi and Osaretin (2015) have found a relationship between money supply, industrial production index, the growth rate of oil prices and consumer prices, the interest rate on time deposits for one month, as well as changes in the exchange rate, and between the share price index on the Nigerian stock market for the period 2001-2017. It was found that the inflation rate and the money supply negatively affected the index in the short and long term, while the industrial production and oil prices had a positive and significant impact on the index in the short and long term. Menike (2006), in his study on the relationship between macroeconomic variables and stock market prices of shares in Sri Lanka for the period 1991-2001, showed that share prices were negatively linked to exchange rates, the rate of inflation and interest rates on treasury bills, while the impact of money supply on stock prices in the mentioned stock market was positive.

Chung and Ariff (2016), in their study on the relationship between money supply, bank liquidity and returns on stock indices in Canada, Japan, the United Kingdom, and the USA in 1990-2013, found that the broader money supply positively affected the stock index in the specified countries.

Bosupeng (2014) discussed the relationship between money supply and stock prices in Botswana in 2011-2013. The study found no positive relationship between money supply and stock prices on the stock exchange mentioned, while other studies support the existence of a positive relationship between the two variables.

Picha (2017) found a positive relationship between money supply and the S\&P 500 for the in- dustry with a 16-month slowdown in the USA; it was found that an increase in deposits and the currency in the American family sector by USD 1 million leads to raising the mentioned index by 0.144 points. Sirucek (2012), in his study on the impact of money supply on the Dow Jones for the American industry over the period 1967-2011, concluded that the presentation of the broad money supply (M2) did not have a significant impact on the index mentioned, while money supply in the broader sense is important for influencing volatility of the Dow Jones Manufacturing stock price index. Adaramola (2011) found that the price of interest, exchange rate, oil prices and gross domestic product (GDP) had a significant impact, at the level of $5 \%$, on stock prices on the Nigerian Stock Exchange in 1985-2009, while money supply in the narrow sense and inflation had no significant effect on share prices.

Muhammad Ahmad Shahid, and Fareena Farheen Kamran (2015) found that stock prices in Pakistan were affected by macroeconomic variables, including inflation rate, the price of production, the price of gold, exports, while prices of silver and imports did not affect stock prices in the stock market of Pakistan in 2005-2014. Hunjra, Chani, Shahzad, Farooq, and Khan (2014) revealed a significant long-term relationship between inflation rate, GDP, price difference, interest rate, and stock prices on the Karachi Stock Exchange in 20012011. According to J. Khan and I. Khan (2018), the presentation of money supply, exchange rate and interest rate significantly affect stock prices on the Karachi Stock Exchange for the long period of time (2001-2016). In the short term, all these variables insignificantly affect stock prices, except for the exchange rate that negatively impacted stock prices on the mentioned stock exchange.

Sampath (2011) analyzed the relationship between macroeconomic variables, such as the real exchange rate, the wholesale price index, and the industrial production index, and revealed they had a significant impact on stock prices in India. Moreover, the industrial production index has 
a significant effect on the long-term stock prices. Also, there was a positive relationship between economic growth and the share price index during 1993-2010.

Oseni and Nwosa (2011) examined the relationship between volatility of the stock market and variability of the macroeconomic indicators in Nigeria in 1986-2010. They found a relationship between GDP and volatility of the stock market, while there was no relationship between interest rate, inflation rate, and stock market volatility in this market.

Kotha and Sahu (2016) discussed the long-term and short-term relationship between macroeconomic indicators and stock returns in India in 2001-2015 and found a positive and significant relationship between the exchange rate, money supply, consumer prices, the interest rate on treasury bills, and the return on the financial market, while they found a negative and insignificant relationship between interest rate and equity returns in the Indian market. Kganyago and Gumba (2015) found a negative correlation between interest rates and monthly stock returns in the Zimbabwe market for the period from April 2009 to December 2013. El-Nader and Alraimony (2012) clarified the impact of macroeconomic variables on the return of shares on the Amman Stock Exchange over the period 1991-2010. The authors realized that the real money supply, inflation, the real exchange rate, changes in the nominal interest rate negatively affected the stock market returns, while an increase in real domestic output positively affected the shares of the stock exchange.

Dayyat (2006) also discussed the impact of monetary policy on the capital market in Jordan over the period 1989-2004 and found a positive relationship between money supply and the issuance of treasury bills and government bonds, and also found that there was a positive relationship between the money supply and the index of share prices in the market mentioned. Al-Shubiri (2013) explained the relationship between macroeconomic variables and the extraordinary returns on the Amman Stock Exchange for 500 industrial companies for the period 2004-2012. The study concluded that the consumer rate index, the size of fixed capital, and money supply significantly affected the returns of stocks, while they did not affect the industrial production index and interest rate on the mentioned returns.

The study by Al-Adayleh (2015) indicated a correlation between macroeconomic variables and the Amman Stock Exchange index in 2001-2014 and showed a positive relationship between the production index, money supply, investor confidence, size of the capital market and the share price index on the Amman Stock Exchange.

Almutair (2015) used joint integration to analyze the relationship between the money supply and the share price index in Saudi Arabia. The study did not prove a long- or short-term causal relationship between the supply money in the narrow or broad sense and the share price index in Saudi Arabia. On the contrary, it found that the share prices of the stock exchange mentioned affected the presentation of money supply in the narrow sense (M1) in the case using the annual data.

Ramadun (2016), in the study on the effect of macroeconomic variables on the movements of share prices on the Amman Stock Exchange for the period 2000-2012, found that there was a negative and significance impact of interest rates and inflation on the movements of shares of industrial companies; besides, the study found that there was a positive statistical effect of both money supply and domestic output on the movements of stock prices of companies mentioned.

A study by Mohamed and Ahmed (2018) on the effect of macroeconomic changes on stock returns in the Amman Stock Exchange-listed companies found that there was a positive and significant relationship between the industrial production, money supply and returns of shares, and a negative relationship between inflation and the price of imports and returns of shares mentioned.

Tawfiq and Thatamouni (2018) explored the impact of monetary and financial policy on stock returns in the Amman Sock Market and found a significant relationship between money supply, inflation, interest, government expenditure, revenues, public debt by one side and the returns of shares for the period 2006-2016 on the stock exchange mentioned. 
Shafiqul, Miah, and Karim (2016) considered the impact of share-to-earnings, share-to-value, return to price, gross domestic product, consumer price index and interest rate margin on the share prices in the stock market of Bangladesh in 20062016. The study found that the stock share from the yield and the stock share from the market value of assets, and the price of the stock to the yield and the consumer price had a significant impact on share prices in the Bangladeshi financial market, while other factors did not affect share prices.

Laith A. Qudah (2012) found a relationship between the balance of payments, the size of the company, the number of users, and the return of shares in companies listed on the Amman Stock Exchange in 2005-2010, while the study did not find any impact of the interest rate, inflation and deficit in the budget and GDP on the rate return of shares.

The study by Momani and Alsharari (2012) aimed to indicate the effect of the macroeconomic factors of interest rate, GDP, money supply and the industrial production index on the stock prices on the Amman Stock Exchange in 1992-2010. The study found a negative relationship between the interest rate and the shares of the banking sector and insurance sector, and a negative relationship between the industrial production index and the index of share prices in the industrial sector and services sector.

In their comparative study, Worlu and Omodero (2017) found a negative impact of gross domestic product, inflation rate and the real exchange rate on the performance of the Nigerian stock market over the period 2000-2015, while it was found that GDP and inflation rate had a negative and significant impact on the stock market in South Africa, and the real exchange rate of the national currency has no impact on the mentioned market during the same period.

D. Chude, Ifurueze, and N. Chude (2015) concluded that the economic growth rate had a positive and significant effect on the stock returns in Nigeria in 1990-2012, while inflation rate, growth rate and money supply had a negative and significant impact on the returns of shares. In this context, Abdulkarim (2014) examines the impact of macroeconomic factors on the returns of common shares of listed Nigerian industrial companies. The study did not find any effect of the inflation rate, interest rate, the exchange rate of the national economy, and gross national income on shares of industrial companies in 1991-2003.

Ouma and Muriu (2014) examined the effect of macroeconomic variables on the returns of shares in Kenya for the period 2003-2013. The study concluded that money supply and inflation rate had a positive and significant impact on the returns of shares in Kenya, while the exchange rate negatively impacted the returns of shares, and interest rates had no significant impact on long-term stock returns on the stock exchange. A study by In'airat (2018) indicates that share prices in the Saudi financial market are positively sensitive to changes in the distribution of shares and oil prices and negatively sensitive to changes in inflation rate over the period 2011-2015.

\section{MONETARY AND FINANCIAL VARIABLES}

Previous studies show that monetary and financial variables have affected share prices traded in the financial markets of emerging and developing countries. Study variables will be considered below.

\subsection{Money supply}

Money supply is a set of tools of payment available in the national economy. The studies have expanded to clarify the relationship between money supply and stock prices; most studies indicate a positive relationship between them because the expansion in money supply increases the liquidity of the national economy, and part of this liquidity moves directly towards the purchase of shares, an increase in profitability of companies and the rise in the prices of shares. Indirectly, an increase in the money supply leads to lower interest rates, stimulates economic growth and is reflected in increased incomes of individuals and increased investment in shares and high prices. This confirms the hypothesis that an increase in money supply will cause inflation and lead to an increase in cash flow in the future and, thus, increase share prices. 


\subsection{Interest rate}

Economic theory indicates that there is a negative relationship between the rate of interest and stock prices; high-interest rates can lead to the recent inflow of foreign capital inward and to an increase in the foreign exchange rate of the national currency, thus, less increase in imports and exports, which is reflected in the decline in the share prices of industrial companies. In this context, some studies on developed financial markets argue that rising interest rates on government securities are prompting investors to shift from investing in stocks to investing in government bonds and deposits in commercial banks, causing stock prices to fall.

\subsection{Inflation}

Fama (1981) noted that the period following 1953 reflected the existence of a negative relationship between inflation and stock prices. This is because share prices are linked to real factors such as investment, production and return on investment, and an increase in the amount of money occurs due to excess liquidity, forcing the authorities, followers of the monetary policy of deflation to absorb the surplus mentioned, resulting in higher interest rates and, as a result, lower current value of cash flows and falling stock prices.

\subsection{Government debt}

The size of the government public debt is an important tool to finance budget deficit. In the case of the government borrowing from the central bank, this policy can be reflected in increased demand for shares and high prices. When the government borrows from the public and commercial banks through issuing government bonds, the adoption of this policy can lead to a drop in demand for shares and the public's tendency to buy bonds, which is reflected in decline in share prices.

\subsection{Government expenditure}

Government expenditure affects the performance of the financial market through the impact of government expenditure on economic activity and the business sector and the family sector on spending behavior. The prosperity of the firms' sector leads to more profitability and distributions to shareholders, which leads to increased demand for shares and the rise in their prices (Mutulis \& Olweny, 2018). According to Maskay (2007) and Sellin (2002), the government can contribute to the increase in stock prices through an expanded financial policy reflected in high GDP and lower unemployment.

\subsection{Budget deficit}

Budget deficit means that the government's expenditure is greater than its revenues. The theory of inflation led by Friedman has confirmed that the government's borrowing from the banking system to finance budget deficit is a strong reason for increasing inflation. Ofori, Danquah, and Zhang (2017) conclude that budget deficit has a negative impact on stock prices as a result of increased financial burden on the government in the future, which leads to a decline in the role of the government in increasing income and, thus, lowering the demand for shares and their prices. While Dayyatt (2016) points out that there is a positive relationship between money supply and the issuance of treasury bills and government bonds to finance budget deficit, resulting in a positive effect of the budget deficit on stock prices. In contrast, Kimathi and Muturi (2016) argued that the issuance of treasury bills and government bonds negatively affected the performance of stock prices in Nigeria's financial market in 2009-2015.

\subsection{Features of commercial banks in Jordan}

At the end of 2018, the number of commercial banks in Jordan reached 25, of which 16 were Jordanian banks, 3 of them were Islamic, and 9 were foreign banks. Jordanian banks conduct banking activities through 806 branches and 79 offices spread throughout the country. At the end of 2017, the total number of population to the total working bank branches in Jordan was 12,470 per branch, compared to one branch for every 13,000 in the USA, which is the most developed and largest, where banks conduct their banking activities in light of a large and sophisticated monetary and financial market, unlike commercial banks in Jordan (Association of Banks in Jordan, 2017). 
Total assets of Jordanian commercial banks reached 35.4 billion dinars, or $76.3 \%$ of total assets of banks in Jordan for 2017 (Association of Banks in Jordan, 2018), while total balance of deposits in banks operating in Jordan amounted to $117 \%$ of GDP, the credit facilities provided by these banks amounted to $87 \%$ of GDP. The proceeds of these banks' investments in the form of treasury bills and bonds amounted to 6.6 billion dinars, representing 23\% of GDP (Association of Banks in Jordan, 2019).

Jordanian banks are small banking units in terms of their capital and banking activities, except for three commercial banks and one Islamic bank. In 2017, foreign deposits are held at 6.799 million dinars, constituting $23.7 \%$ of total deposits (Central Bank of Jordan, 2018). This is often not independent enough and leads to directing these deposits to foreign investment abroad, since the private sector moves in the face of mistrust in the local economy and fears of the instability of the domestic currency to maintain savings in US dollars despite the low-interest rate compared to Jordanian dinar, so these balances remain outside the control of the central bank.

The banking market is monopolistic, with five banks accounting for $80 \%$ of their total assets and liabilities. The commercial securities market is limited to easy borrowers to borrow directly from banks, and there is no developed market for banking acceptances. Certificates of deposit were issued in 1993, and the central bank created auctions for selling to commercial banks and insurance companies and since 2000 reduced its issuance and replaced them with commercial tools such as repurchase agreements and overnight loans and deposits (AlSayed, 2001).

\subsection{Share index}

The share index of Jordanian commercial banks is weighted by the free market value of 13 banks, whose assets constitute $76 \%$ of the total assets of banks operating in Jordan. This reflects the high representation of a sample for the Jordanian banking market (Association of Banks in Jordan, 2019). Free shares mean the number of shares of banks actually traded on the stock exchange, where the weight of banks is given in this index based on the weighted market value of free shares listed for trading, and not on the number of total shares, and does not include shares owned by the board of directors and the parent companies or the ally. This index is more representative of changes in share prices of commercial banks. Many international institutions use this approach to calculate the standard index, such as Standard \& Poor (S\&Ps) and the two companies of Dow Jones and STOXX (ASE, 2018). The banking sector affected the Amman Stock Exchange. In 2017, the volume of trading in the financial and banking sector dominated $65 \%$ of turnover. The banking sector index doubled that of the Amman Stock Exchange. The banking sector also contributes $83.8 \%$ to the financial sector index in 2017. (ASE, 2017).

\section{AIMS AND HYPOTHESES}

This study aims to determine the effect of monetary and financial variables on share prices of Jordanian commercial banks during the period (2001-2018), identifying the most important factors affecting these prices, and providing information to investors in the financial market in order to ensure prudent decisions about trading in commercial banks' shares.

To determine whether the monetary and financial variables have an effect on the prices of shares of Jordanian commercial banks, the study is based on the following questions:

I. Is there a statistical significance of monetary variables represented by M2 money supply, the interest rate on time deposits, and inflation on the price of shares of commercial banks in Jordan for the period 2001-2018?

II. Is there a statistical significance of financial variables represented by budget deficit, domestic public debt, and government expenditures on the prices of shares of commercial banks in Jordan for the period 2001-2018?

To answer the study questions, the following hypotheses were formulated:

H1: There is a statistically significant positive effect of the M2 money supply on the price of shares of Jordanian commercial banks. 
Table 1. Hypothesis testing and results

\begin{tabular}{|c|c|c|c|c|}
\hline Variables & Coefficients & T-statistics & Probability & Std. error \\
\hline$A$ & -0.0278 & -0.1821 & 0.8591 & 0.1531 \\
\hline $\mathrm{M} 2$ & 5.232 & 2.678 & 0.0232 & 1.9536 \\
\hline $\operatorname{lnf}$ & 0.00036 & 0.7454 & 0.4731 & 0.000486 \\
\hline Int & -0.0418 & -0.1366 & 0.8940 & 0.3057 \\
\hline DB & -0.0938 & -2.592 & 0.0269 & 0.0362 \\
\hline DD & -1.8276 & -2.7189 & 0.0216 & 0.6721 \\
\hline $\mathrm{GE}$ & 0.875 & 0.6886 & 0.50671 & 1.2707 \\
\hline$R^{2}$ & 0.63 & - & - & - \\
\hline Adjusted $R^{2}$ & 0.402 & - & - & - \\
\hline F.s (statistic) & 02.65 & - & - & - \\
\hline Prob. (F. statistic) & 0.072 & - & - & - \\
\hline D.W. & 1.71 & - & - & - \\
\hline
\end{tabular}

H2: There is a statistically significant positive effect of inflation on the price of shares of Jordanian commercial banks.

H3: There is a statistically significant positive effect of interest rate on the price of shares of Jordanian commercial banks.

H4: There is a statistically significant positive effect of budget on the price of shares of Jordanian commercial banks.

H5: There is a statistically significant positive effect of debt on the price of shares of Jordanian commercial banks.

H6: There is a statistically significant positive effect of government expenditure on the price of shares of Jordanian commercial banks.

\section{METHODOLOGY}

This study is mainly based on the secondary data issued by official institutes. Share prices data of Jordanian commercial banks were collected from the reports issued by the Amman Stock Exchange for the annual securities. The data related to money supply, inflation, budget deficit, and government expenditure have been obtained from the annual reports issued by the Central Bank of Jordan and the Association of Jordanian Banks over the period (2000-2018).

\subsection{Study model}

To illustrate the effect of independent variables on the prices of shares of Jordanian commercial banks, the multiple linear regression equation is developed, depending on the E-Views program to test this effect, taking the annual rate of change in the mentioned variables as follows:

$$
\begin{aligned}
& S P T=\alpha+B o M 2+B 1 \text { Inf }+ \\
& +B 2 \text { Int }+B 2 D B+B 3 G D E+ \\
& +B 4 G E+\varepsilon,
\end{aligned}
$$

where $M 2$ = Money supply in the broader sense, $I N F=$ Consumer price index, $I N T=$ Interest rate on deposits, $D B=$ Budget deficit, $G D E=$ Government debt, $G E=$ Government expenditure, and $B 0-B 4=$ Volatility in stock prices caused by the effect of independent variables.

\subsection{Results}

Table 1 shows the results of the regression analysis between the share prices of Jordanian commercial banks and independent variables that influence them as follows:

1 - There is a significant positive effect of $M 2$ on the shares of Jordanian commercial banks at a level of significance of less than $5 \%$, which is 0.0232 , and the value of the money supply factor $(B)$ is 5.232. This means that rising money supply by $1 \%$ leads to an increase in prices of securities of Jordanian commercial banks at a rate of $5.232 \%$, and it is a strong impact of money supply on the shares of commercial banks.

On this basis, the first hypothesis is rejected, indicating the absence of a significant and positive effect of the presentation of money supply on the share prices of commercial banks, and an alternative hypothesis is accepted about a positive and 
significant impact of the presentation of money supply on the share prices of commercial banks for the period 2001-2018.

This result is in line with the studies by Ramadun (2016), Sirucek (2012), Maskay (2007), J. Khan and I. Khan (2018), Tawfiq and Tahtamoun (2018), Mohammed and Ahmed (2018), AlShubiri (2013), Menike (2006), Momani and Alsharari (2012) which found a positive and significant effect of money supply on the returns of shares, and agreed that there is a positive effect of money supply on the share prices using the Keynes structural model that an increase in money supply leads to a decrease in interest rates and an increase in both investment and total output, which has a positive effect on stock returns and high prices in financial markets.

However, this positive effect of money supply on the share prices of Jordanian commercial banks is inconsistent with the study by Tawfiq and Tahtamoun (2018), who argue that there is no impact of money supply on the stock exchange on the Amman Stock Exchange for the period 2006-2016, and with El-Nader and Alraimony (2012), who found that increased money supply had a negative impact on returns of shares on the Amman Stock Exchange in 1991-2010.

2 - There is no statistical significant effect of inflation on the prices of securities of Jordanian commercial banks, where the statistical significance level (Sig) is 0.473 and is not statistically significant at the level of significance 5\%. This result indicates that there is no positive effect of inflation on the share prices of Jordanian commercial banks, thus, the second hypothesis is accepted, which indicates that there is no positive effect of inflation on the prices of shares of Jordanian commercial banks. This means that there are other factors than the inflation rate effect on share prices of Jordanian banks - the expected return on alternative investment. This result is in line with J. Khan and I. Khan (2018), Oseni and Nwosa (2011), Garba (2014), and inconsistent with Shafiqul, Miah, and Karim (2016), In'airat (2018), Mohammed and Ahmed (2018), Ramadun (2016), Duy (2016), D. Chude, Ifurueze, and N. Chude (2015), Omornyi and Osaretin (2015), who indicated a negative impact of inflation on securities prices. Also, this result is not consistent with the findings that indicated a positive effect of inflation on the prices of securities such as Tawfiq and Tahtamoun (2018), Ouma and Muriu (2014), and Al-Shubiri (2013).

3 - There is a negative but not statistically significant effect of interest rate on the share prices of Jordanian commercial banks for the period 2001-2018, where the statistical level reached 0.4731 , which is not statistically significant at the $5 \%$ level of significance. Therefore, the third hypothesis is accepted that indicates no effect of the interest rate on the share prices of commercial banks in Jordan. This refers to the decision of investors on the demand for shares of Jordanian commercial banks, which is not affected by the change in the interest rate on timed deposits, but due to the interest of investors in the potential profit on shares of commercial banks. This is inconsistent with the economic theory that indicates that the rise in the interest rate on time deposits encourages investors to deposit in commercial banks and reduce the demand for shares of commercial banks.

Also, an increase in interest rates leads to an increase in the cost of borrowing to purchase securities, which reduces the demand for shares of commercial banks and reduces their value. This result is not consistent with the studies that indicated the negative impact of interest rates on the returns of shares on different stock exchanges. In contrast, this result is in line with Manike (2016), Duy (2016), Ramadun (2016), J. Khan and I. Khan (2018), Shafiqul et al. (2016). Momani and Alsharari (2012), Ligocká, Pražák, and Stavárek (2016), Tawfiq and Thatamouni (2018), who indicate that there is no impact of interest rates on the returns of shares on the Amman Stock Exchange.

4 - There is a negative and statistically significant effect of budget deficit on share prices of Jordanian commercial banks, where the level of significance reached 0.0269 . This means that a $1 \%$ increase in budget deficit leads to a decline in share prices of commercial banks by $2.6 \%$, which is statistically significant at the level of $5 \%$. Thus, the fourth hypothesis is rejected and the alternative hypothesis is accepted that indicates a statistically significant negative impact 
of budget deficit on share prices of Jordanian commercial banks. The negative impact can be explained by the inability of budgetary measures for the future burden of the government to pay off the government debt burden, resulting in a future decline in incomes and a lack of demand for bank shares and lower their prices. This finding is inconsistent with the study of Laith A. Qudah (2012), which found that the budget deficit had no significant effect on share returns on the Amman Stock Exchange for the period 2005-2010.

5 - There is a positive and statistically significant effect of domestic debt (DD) on securities prices of Jordanian commercial banks at a level of significance 0.0216 . This means that an increase in the general government debt by $1 \%$ leads to an increase in share prices of commercial banks by $2.2 \%$. Thus, the fifth hypothesis is refused and the alternative hypothesis is accepted, which indicates the impact of domestic public debt on the shares of Jordanian commercial banks.

This result is consistent with the study of Mutulis and Olweny (2018), which indicates that domestic debt has a positive effect on the performance of the stock market on the Nairobi Stock market. The internal government debt is direct and present in increased expenditure and income, thus increasing the demand for commercial bank shares, in addition to the fact that domestic debt burdens are less than those of external debt. This effect is considered a spot effect, which in the future can lead to a negative impact on the demand for bank shares, when the government pays debts, especially if the internal debt burden is heavy for the government. But this result is inconsistent with that reached by Kimathi and Muturi (2016), who indicated that treasury bills and government bonds neg- atively affected the performance of stock prices in the Nigerian market.

6 - There is a positive but not statistically significant effect of government expenditure on share prices of Jordanian commercial banks, where the statistical level reached 0.5067 , which is not statistically significant at the $5 \%$ level. The lack of influence of government expenditure on stock prices may be due to the fact that these expenditures are mainly current government expenditures, and not investments, which is not reflected in the increase in gross domestic production. This result is not consistent with the economic theory that suggests that the government can contribute to the increase in stock prices when pursuing an expansionary fiscal policy. This leads to increased income and reduced unemployment rate, or the role of government expenditure on stock prices comes through its effect on income and distributions.

This result is inconsistent with studies by Kimathi and Muturi (2016) and Ouma and Muriu (2001) about the performance of the financial market in Kenya, and the study by Mutulis and Olweny (2018) about the performance of the financial market in Nairobi, which indicated that government expenditure had a significant impact on the performance of the stock market in these markets. Also, this result is not consistent with a study by Namini and Nasab (2015), which indicated that government spending had a negative impact on the share prices in Iran.

Finally, the regression model reached $\mathrm{R}^{2}=0.63$, and this means that $63 \%$ of changes in share prices of Jordanian commercial banks is due to changes in the independent variables included in the model. Moreover, the model is significant at the 0.07 level.

\section{CONCLUSION}

This study has concluded that monetary and financial variables have an impact on share prices of Jordanian commercial banks for the period 2001-2018. The results show that the share prices of commercial banks in Jordan interact strongly with the money supply in the broad sense (M2), where an increase in the money supply is reflected positively in the rising prices of shares. Also, there is a significant and negative effect of budget deficit on the share prices; an increase in defi- 
cit leads to a decline in the prices of shares of commercial banks and may be associated with an increase in the size of the burden on the government to repay its debts, which leads to a drop in income and a lack of demand for shares of banks. In addition, there is a positive effect of domestic debt on banks' share prices; an increase in the internal debt will lead to an increase in spending and income, and a part of this increase will be directed towards buying shares in Jordanian commercial banks, which will drive up share prices, although this positive impact could turn into a negative impact in the future when the government pays its debt obligations. Also, there is no effect of both inflation and interest rate on the share prices of banks during the mentioned period. This means that there are factors other than inflation and interest rate that affect share prices of banks, such as the investors' expectations about the rate of return on other assets, as well as moderate and not excessive inflation in Jordan. Finally, there is no significant statistical effect of government expenditures on the share prices of banks. In general, government expenditures are mostly current and not capital expenditures, therefore, they do not contribute to an increase in the growth rates required for domestic product and banks share prices.

\section{RECOMMENDATIONS}

Based on the above conclusions, the study recommends the following:

1) Since the money supply has a positive effect on share prices of commercial banks, monetary authorities must achieve harmony between changes in the money supply and changes in share prices of commercial banks and choose appropriate monetary policies to help investors make the right decisions on the sale and purchase of shares in the financial market.

2) The results also show a positive impact of the domestic government debt on share prices of Jordanian commercial banks. Therefore, the focus should be on financing the budget deficit through internal debt because of low burden it bears compared to external debt, which is paid in foreign currency.

3) Financial authorities should reduce the budget deficit to reasonable levels of up to 3\% of GDP in order to reduce the burden on the central government and avoid the negative impact of the budget deficit on share prices of Jordanian commercial banks considered in the study.

4) Financial authorities should consider increasing the share of capital expenditures compared to the current expenses and its role in increasing production and reducing unemployment.

5) Monetary policymakers must provide investors with monetary and financial statements and show their impact on stock prices in order to help investors make more accurate and effective decisions when investing in securities.

\section{AUTHOR CONTRIBUTIONS}

Conceptualization: Hel Ajmi Jameel Al-Dhaimesh.

Data curation: Hel Ajmi Jameel Al-Dhaimesh.

Funding acquisition: Hel Ajmi Jameel Al-Dhaimesh.

Investigation: Hel Ajmi Jameel Al-Dhaimesh.

Methodology: Hel Ajmi Jameel Al-Dhaimesh.

Software: Hel Ajmi Jameel Al-Dhaimesh.

Supervision: Hel Ajmi Jameel Al-Dhaimesh.

Writing - original draft: Hel Ajmi Jameel Al-Dhaimesh. 


\section{REFERENCES}

1. Abdulkarim, G., (2014). Impact of Dividend- Per- Share on Common Stock Returns: A Case Study of Some Selected Manufacturing Firms Listed on the Nigerian Stock Exchange. European Journal of Business and Management, 6(30), 36-43. Retrieved from https://www.iiste.org/Journals/ index.php/EJBM/article/ view/15611

2. Adaramola, A. O. (2011). the impact of macro-economic indicators on stock prices in Nigeria. Developing Country Studies, 1(2), 1-15. Retrieved from https://www.researchgate. net/publication/268364362_The_ Impact_of_Macroeconomic Indicators_on_Stock_Prices_in_ Nigeria

3. Al-Adayleh, R. M. (2015). Investigation the equilibrium relationship micro and macroeconomic variables and Amman stock exchange (ASE) index through ARDI Model (the bound test approach). International Journal of Business and Statistical Analyses, 2(1), 55-61. http://dx.doi. org/10.12785/IJBSA/020105

4. Almutair, S. (2015). A cointegration analysis of money supply and Saudi stock price index. International Journal of Economics and Finance, 7(5), 153-165. http:// dx.doi.org/10.5539/ijef.v7n5p153

5. AlSayed Ali, A. M. (2001, August). The evolution of monetary policy in Jordan 1970-1999 (pp. 11-12). A handbook for research and studies.

6. Al-Shubiri, F. N. (2013). Analysis of the relationship between economic factors and abnormal stock return empirical evidence. Polish Journal of Management Studies, 8(1), 7-15. Retrieved from https://econpapers.repec.org/ article/pczjournl/v_3a8_3ay_3a20 13_3ai_3a1_3ap_3a7-15.htm

7. Amman Stock Exchange (ASE). (2017). Annual report. Retrieved from https://exchange.jo/sites/ default/files/2019-02/ASE_ Annual_Repor_2017_E.pdf

8. Amman Stock Exchange (ASE). (2018). Annual report. Retrieved from https://exchange.jo/sites/ default/files/2019-07/ASE\%20 Annual\%20Report\%20English\%20 2018.pdf

9. Ananwude, A. C., Echekoba, F. N., Okaro, C. S., \& Akuesodo, O. E. (2017). Monetary policy and capital market performance: an empirical evidence from Nigerian data. Research Journal of Economic, 1(3), 1-5. Retrieved from https:// www.ssoar.info/ssoar/handle/ document $/ 56320$

10. Association of banks in Jordan. (2007-2019). Annual report. Retrieved from http://www.abj.org. jo/Pages/viewpage?pageID=76

11. Bosupeng, M. (2014). Sensitivity of stock prices to money supply dynamics (MPRA Paper No. 77924). Retrieved from https://core.ac.uk/download/ pdf/211623225.pdf

12. Central Bank of Jordan. (20102018). Annual report. Retrieved from https://www.cbj.gov.jo/ Pages/viewpage.aspx?pageID=337

13. Central Bank of Jordan. (2018, October). Monthly Statistical Bulletin, 56(10), 22.

14. Chude, D. I., Ifurueze, M. S., \& Chude, N. P. (2015). Impact of some selected macroeconomic variables on stock market returns in Nigeria. EPRA International Journal of Economic and Business Review, 3(12), 29-35. Retrieved from https://eprawisdom.com/ jpanel/upload/articles/112am4. Chude,\%20Daniel\%20 Izuchukwu,\%20Dr.\%20M.S.\%20 Ifurueze $\% 20 \& \% 20$ Chude, $\% 20$ Nkiru\%20Patricia.pdf

15. Chung, T., \& Ariff, M. (2016) Money supply, banking, liquidity and stock index returns: evidence from four major capital markets. Business and Economic Journal, 7(3), 1-9. Retrieved from https:// www.hilarispublisher.com/openaccess/money-supply-bankingliquidity-and-stock-index-returnsevidence-fromfour-major-capitalmarkets-2151-6219-1000212.pdf

16. Dayyat, R. A. (2006). The impact of monetary policy on the capital market: the case of Jordan (Ph.D. Thesis). Coventry University. Retrieved from https:// curve.coventry.ac.uk/open/ items/2483843b-c240-a4a9-04463f06d15fb134/1/

17. Duy, V. Q. (2016). The impact of macro-economic factors on stock price index, $\mathrm{VN}$-index. International Journal of Innovative Science Engineering and Technology, 3(7), 69-89. Retrieved from http:// ijiset.com/vol3/v3s7/IJISET_V3_ I7_06.pdf

18. El-Nader, H. M., \& Alraimony, A. D. (2012). The impact of macroeconomic factors on Amman stock market returns. International Journal of Economic and Finance, 4(12), 202-213. https://doi. org/10.5539/ijef.v4n12p202

19. Garba, A. (2014). Impact of Macroeconomic Factors on Common Stock Returns: A Study of Listed Manufacturing Firms in Nigeria. European Journal of Business and Management, 6(13), 140-146. Retrieved from https:// iiste.org/Journals/index.php/ EJBM/article/view/12699/12974

20. Hunjra, A. I., Chani, M. I., Shahzad, M., Farooq, M., \& Khan, K. (2014). Impact of macroeconomic variables on stock prices in Pakistan. International Journal of Economics and Empirical Research, 2(1), 13-21. Retrieved from https://mpra.ub.unimuenchen.de/60791/1/MPRA_ paper_60791.pdf

21. In'airat, M. (2018). The effect of internal and external factors on stock market prices - evidence from Saudi Arabia. The Business and Management Review, 9(3), 413-423.

22. Kganyago, T., \& Gumbo, V. (2015). An empirical study of the relationship between money market interest rate and stock market performance: evidence from Zimbabwe (2009-2013). International Journal of Economic and Financial Issue, 5(3), 638646. Retrieved from http://www. econjournals.com/index.php/ijefi/ article/view/1202 
23. Khan, J., \& Khan, I. (2018). The impact of macroeconomic variables on stock prices: a case study of Karachi stock exchange. Business and Economics Journal, 9(13), 15-25. Retrieved from https://www.researchgate.net/ publication/328142277_The_ Impact_of_Macroeconomic Variables_on_Stock_Prices_A_ Case_Study_of_Karachi_Stock_ Exchange

24. Kimathi, M., \& Muturi, W. (2016). The relationship between government domestic debt and stock performance in Kenya. International Journal of Social Sciences and Information Technology, 2(9), 1035-1051. Retrieved from https://www. ijssit.com/main/wp-content/ uploads/2016/10/THERELATIONSHIP-BETWEENGOVERNMENT-DOMESTICDEBT-AND-STOCKPERFORMANCE-IN-KENYA.pdf

25. Kotha, K. K., \& Sahu, B. (2016). Macro-economic factors and the Indian stock market. International Journal of Economics and Financial Issues, 6(3), 1081-1091. Retrieved from https://ideas.repec.org/a/eco/ journ1/2016-03-34.html

26. Laith A. Qudah, M. A. (2012). The factors that effect on shares return in Amman stock market. Interdisciplinary Journal of Contemporary Research in Business, 4(6), 1219-1223. Retrieved from https://journal-archieves24.webs. com/1219-1231.pdf

27. Ligocká, M., Pražák, T., \& Stavárek, D. (2016). The Effect of Macroeconomic Factors on Stock Prices of Swiss Real Estate Companies. Acta Universitatis Agriculturae Et Silviculturae Mendelianae Brunensis, 64(6), 2015-2024. https://doi.org/10.11118/ actaun201664062015

28. Maskay, B. (2007). Analyzing the effect of change in money supply on stock prices. The Park Place Economist, 15(1), 72-79. Retrieved from https://digitalcommons.iwu. edu/parkplace/vol15/iss1/16/

29. Menike, L. (2006). The effect of macroeconomic variables on stock prices in emerging Sri Lankan stock market. Sabaragamuwa University Journal, 6(1), 50-67. http://doi.org/10.4038/suslj. v6il.1689

30. Mishkin, F. S. (2010). The economics of money, banking and financial markets (9th ed.). Prentice Hall. Retrieved from https://www.twirpx.com/ file/1120806/

31. Mohamed, I. A., \& Ahmed, S. (2018). The effect of macroeconomic variables on stock returns in the Jordanian stock market. Global Journal of Management and Business, 5(2), 87-93. Retrieved from https://premierpublishers.org/ gjmb/031020189579

32. Momani, G. F., \& Alsharari, M A. (2012). Impact of economic factors on the stock prices at Amman stock market (19922010). International Journal of Economic and Finance, 4(1), 151159. https://doi.org/10.5539/ijef. v4n1p151

33. Muhammad Ahmad Shahid, \& Fareena Farheen Kamran. (2015). Causal relationship between macroeconomic factors and stock prices in Pakistan. International Journal of Management and Commerce Innovations, 3(2), 172178. Retrieved from https://www. slideshare.net/AhmedShahid/ causal-relationship-betweenmacroeconomic-factors-andstock-prices-in-pakistan

34. Mutulis, M. V., \& Olweny, T. (2018). The effect of fiscal policy on the performance of the Nairobi securities exchange in Kenya. International Journal of Economic, Commerce and Management, 6(6), 294-306. Retrieved from http://ijecm.co.uk/wp-content/ uploads/2018/06/6622.pdf

35. Namini, T., \& Nasab, Z. (2015) The Impact of Monetary and Fiscal Policies on Iran's Stock Market: An SVAR Approach. Journal of Applied Environmental and Biological Sciences, 5(9), 767 775. Retrieved from https://www. semanticscholar.org/paper/TheImpact-of-Monetary-and-FiscalPolicies-on-Stock-Namini-Nasab/ 40b5b63859b398e56d26852e427c0 $9 \mathrm{c} 3 \mathrm{c} 1882 \mathrm{e} 9 \mathrm{~b}$

36. Ofori, C., Danquah, B., \& Zhang, X. (2017). The Impact of Money Supply on Inflation, A Case of Ghana. Imperial Journal of Interdisciplinary Research, 3(1), 2312-2318. Retrieved from https://www.researchgate.net/ publication/314151566_The_ impact_of_money_supply_on_ inflation_a_case_of_Ghana

37. Olowe, R. A. (2007). The relationship between stock prices and macro-economic factors in the Nigerian stock market. African Review of Money Finance and Banking, 2007, 79-98. Retrieved from https://www.jstor.org/ stable/41410527

38. Omornyi, A., \& Osaretin, A. (2015). The impact of macroeconomic variables on stock market index in Nigeria. African Journal of Management Sciences, 1(1), 18-40. Retrieved from https://www.researchgate. net/publication/326403154 THE_IMPACT_OF_ MACROECONOMIC_ VARIABLES_ON_STOCK_ MARKET_INDEX_IN_NIGERIA

39. Oseni, I. O., \& Nwosa, P. I. (2011). Stock market volatility and macroeconomic variables volatility in Nigeria: an exponential GARCH approach. European Journal of Business and Management, 3(12), 43-53. Retrieved from https://www.iiste. org/Journals/index.php/EJBM/ article/view/721

40. Ouma, W. N., \& Muriu, P. (2014). The impact of macro-economic variables on stock market returns in Kenya. International Journal of Business of Commerce, 3(11), 1-31. Retrieved from https://www. ijbcnet.com/3-11/IJBC-14-31001. pdf

41. Picha, V. (2017). Effect of money supply on the stock market. Acta Universitatis Agriculturae et Silviculturae Mendelianae Brunensisuniversity, 65(2), 465473. https://doi.org/10.11118/ actaun201765020465

42. Ramadun, I. Z. (2016). Macroeconomic approach 
of the determinants of stock price movements in Jordan. Asian Journal of Finance and Accounting, 8(2), 60-69. https://doi. org/10.5296/ajfa.v8i2.8616

43. Sampath, T. (2011). Macroeconomic variables and stock prices in India: An empirical analysis. The IUP Journal of Monetary Economy, 9(4), 4354. Retrieved from https:// www.researchgate.net/ publication/256031823 Macroeconomic_Variables_and_ Stock_Prices_in_India_An_ Empirical_Analysis

44. Sellin, P. (2002). Monetary Policy and the Stock Market: Theory and Empirical Evidence. Journal of Economic Surveys, 15(4), 491-541. https://doi.org/10.1111/14676419.00147

45. Shafiqul, A., Miah, R., \& Karim, A. (2016). Analysis on Factors that Affect Stock Prices: A Study on Listed Cement Companies at Dhaka Stock Exchange. Research Journal of Finance and Accounting, 7(18), 93-113. Retrieved from https://iiste.org/Journals/index. php/RJFA/article/view/33297

46. Sirucek, M. (2012).

Macroeconomic variables and stock market: US review (MPRA Paper No. 39094). Retrieved from https://mpra.ub.uni-muenchen. de/39094/

47. Tawfiq, T. T., \& Tahtamoun, A. (2018). The impact of monetary and fiscal policies on stock returns in the Jordanian Amman stock exchange case. Research Journal of Finance and Accounting, 9(6), 155-128. Retrieved from https://www.iiste.org/Journals/ index.php/RJFA/article/ view/41579

48. Worlu, C. N., \& Omodero, C. O. (2017). A comparative analysis of macro-economic variables and stock market performances in Africa (2000-2015). International Journal of Academic in Accounting Finance and Management Sciences, 7(4), 95-102. Retrieved from https://hrmars.com/ hrmars_papers/Article_09_A_ Comparative_Analysis_of_ Macroeconomic_Variables.pdf 